\title{
TERJADINYA PENCURIAN YANG DILAKUKAN OLEH ANAK DI KOTA PALOPO
}

\author{
Andi Takdir Jufri \\ Dosen Universitas Andi Jemma Palopo
}

\begin{abstract}
Theft cases are committed by children in Palopo from year to year has increased. Contributing factor is the factor of family environment, social environment factors and factors of socio-economic conditions and the factors of the low level of education of the child. The efforts made by law enforcement officials are concerned, the main apparatus Palopo to cope with the offense of theft committed by children, the preventive measures (prevention) to provide guidance to parents about the importance of the relationship of familiarity family, coaching religious, cooperation between teachers and pupils on how to learn in school and outside of school. Repressive efforts are taking action raids, prosecution/investigation and detention.
\end{abstract}

Keywords:

Child, Criminal, Social Environment

\begin{abstract}
Abstrak
Kasus pencurian yang dilakukan oleh anak di Kota Palopo dari tahun ke tahun mengalami peningkatan. Faktor penyebabnya yaitu, faktor lingkungan keluarga, faktor lingkungan pergaulan dan faktor kondisi sosial ekonomi serta faktor minimnya tingkat pendidikan anak tersebut. Upaya yang dilakukan oleh aparat penegak hukum yang terkait, utamanya aparat Kota Palopo untuk menanggulangi delik pencurian yang dilakukan oleh anak, yakni upaya preventif (pencegahan) dengan memberikan bimbingan kepada orang tua anak mengenai pentingnya hubungan keakraban keluarga, pembinaan keagamaan, menjalin kerjasama antara guru murid tentang cara belajar di sekolah maupun di luar sekolah. Upaya Represif yaitu melakukan tindakan razia, pengusutan/penyidikan dan penahanan.
\end{abstract}

Kata Kunci:

Anak, Tindak Kriminal, Lingkungan Sosial

\section{A. PENDAHULUAN}

ebagaimana yang tertuang dalam pembukaan Undang-Undang Dasar 1945 $(7$ yang mana bangsa Indonesia harus mencerdaskan kehidupan bangsa Indonesia dan menciptakan moral serta etika bangsa. Sehubungan dengan itu 
dalam rangka usaha pembangunan nasional dilaksanakan demi untuk mewujudkan tujuan nasional. Adapun tujuan nasional adalah mewujudkan suatu masyarakat adil dan makmur yang merata materill dan spiritual berdasarkan Pancasila dan Undangundang Dasar 1945 dalam Wadah Negara Kesatuan Republik Indonesia yang merdeka, bersatu, berdaulat dan berkedaulatan rakyat dalam suasana perikehidupan bangsa aman, tentram, tertib dan dinamis dalam lingkungan pergaulan dunia yang bersahabat dan damai yang disertai dengan norma-norma dan adat terutama norma hukum yang perlu mendapat perhatian.

Dengan demikian maka dapat dikaitkan bahwa, kenakalan anak baik pada tingkat perilaku menyimpang sebagaimana perbuatan yang tidak lazimnya anakanak remaja atau pada tataran kenakalan remaja ke arah kriminal bagi kita bukan saja menjadi masalah sosial, akan tetapi sudah menjadi masalah yang serius yang kajian kriminologi ataupun dari sudut pandang psikologi sosiologi hukum, yang sampai saat ini belum dapat diatasi secara tuntas. Akibat yang ditimbulkan cukup serius dan tidak dapat lagi dianggap sebagai suatu persoalan biasa lagi, sebab tindakan-tindakan delinquency banyak yang menjurus kepada tindakan kriminal.

Di Indonesia hukum pidana yang mengatur segala sesuatu tentang kejahatan dan pelanggaran serta penghukuman atasnya, di muat dalam Kitab Undang-undang Hukum Pidana (KUHPidana). Untuk Indonesia Undang-undang, ini dalam pelaksanaannya dilengkapi dengan hukum acara (prosedur) pidana, yang terakhir mulai berlaku permulaan tahun 1982 dan terdapat dalam Kitab Undang-undang Hukum Acara Pidana (KUHAP), yang menggantikan peraturan-peraturan sebelumnya. Selain itu kejahatan yang dilakukan oleh anak juga telah diatur tersendiri dalam undang-undang No.3 Tahun 1997 Tentang Pengadilan Anak, dan ketentuan yang mengatur tentang perlindungan hak-hak anak, yaitu dengan ditetapkannya undang-undang No. 23 Tahun 2002 Tentang Perlindungan Anak. Sehingga tindakan kriminal atau kejahatan yang dilakukan oleh anak, seperti "Delik Pencurian" yang dilakukan oleh anak, perlu mendapat pengkajian dan pertimbangan khusus yang serius, sehingga pemberian sanksi tidak meninggalkan aspek pembinaan, dan dari sisi lainnya tidak melanggar perlindungan hak-hak anak.

Tentunya kita mengetahui bahwa Kejahatan (crime) yang dilakukan oleh orang dewasa, tidak dapat disamakan begitu saja dengan kenakalan anak atau remaja yang biasa dilakukan oleh anak, sebab harus dibedakan sifat dan bentuk perbuatan seorang anak dengan perbuatan orang dewasa. Perbuatan orang dewasa didasari sikap kesengajaan dalam arti penuh, telah dipertimbangkan dan dipikirkan secara masak.

\section{Rumusan Masalah}

Berdasarkan latar belakang di atas, maka penulis akan mengarahkan serta memberikan batasan sebagai berikut :

- Faktor apakah yang menyebabkan terjadinya delik pencurian yang dilakukan oleh anak di Kota Palopo? 
- Upaya apa yang dilakukan untuk mengurangi terjadinya delik pencurian yang dilakukan oleh anak di Kota Palopo?

\section{Tujuan Penelitian}

- Untuk mengetahui penyebab utama terjadinya delik pencurian yang dilakukan oleh anak di Kota Palopo.

- Untuk mengetahui upaya yang dilakukan oleh aparat penegak hukum dalam menanggulangi delik pencurian yang dilakukan oleh anak di Kota Palopo.

\section{Manfaat Penelitian}

- Sebagai bahan masukan bagi masyarakat pada umumnya dan bagi para penegak hukum pada khususnya, untuk dapat mengambil langkah-langkah dalam upaya pencegahan atau mengurangi terjadinya pencurian yang dilakukan oleh anak.

- Agar dapat menjadi salah satu bahan referensi dalam mengetahui perkembangan pencurian yang terjadi di Kota Palopo.

\section{B. TINJAUAN PUSTAKA}

\section{Pengertian tentang Kejahatan}

Dari beberapa literatur yang menerangkan tentang arti kejahatan ( delik ), maka penulis akan memberikan suatu pengertian. Secara etimologi, istilah kriminologi berasal adri kata "crime" dan "logos". Crime berarti kejahatan,.(Abdulsyani, 1987:6).

Sutherland dan Cressy (Moeljatno, 1986 : 52), menyatakan bahwa :

Kriminologi adalah suatu ilmu pengetahuan mengenai kejahatan sebagai gejala sosial, mengemukakan tentang ruang lingkup kriminologi yang mencakup proses perbuatan hukum, dan reaksi sosial atas pelanggaran hukum.

Demikian pula apa yang diungkapkan oleh Savitri dan John (Romli Atmasasmita, 1987 :83) bahwa kriminologi, adalah :

Menurut Andi Zainal Abidin Farid (1981:145) istilah paling tepat adalah delik yang berasal dari bahasa Latin yaitu delictum atau delicta, dengan alasan bahwa:

1. Karena delik bersifat universal, semua orang di dunia mengenalnya;

2. Karena delik bersifat ekonomis karena singkat;

3. Karena tidak menimbulkan kejanggalan seperti peristiwa pidana, perbuatan pidana (bukan peristiwa pidana, perbuatan pidana yang dipidana tetapi pembuatnya);

4. Karena delik luas pengertiannya sehingga meliputi juga delik-delik yang diwujudkan oleh koorporasi, orang mati, orang tidak dikenal menurut hukum pidana ekonomi indonesia.

\section{Pengertian tentang Usia Anak}

Pengertian anak masih merupakan masalah aktual dan sering menimbulkan kesimpangsiuran pendapat diantara para ahli hukum, salah satu diantaranya adalah 
berapa maksimun batas umur yang ditentukan bagi seorang anak.

Kita mengetahui bahwa usia anak adalah usia yang harus diperhatikan karena menyangkut masa depan anak. Anak harus mendapat perhatian yang serius demi untuk masa depan yang cerah. Masalah anak atau dengan kata lain adalah belum dewasa sering dipakai untuk menunjukkan keadaan dimana seorang secara yuridis atau secara hukum belum mampu bertanggung jawab atas perbuatan-perbuatan yang telah dan atau akan dilakukan.

Undang-undang Nomor 3 Tahun 1997, Tentang Pengadilan Anak dalam pasal 1 ayat (1), ditegaskan bahwa:

Ayat adalah orang yang dalam perkara Anak nakal lebih mencapai umur 8 (delapan) tahun tetapi belum mencapai 18 (delapan belas) tahun dan belum pernah kawin.

Dalam Undang-undang Nomor 23 Tahun 2002 Tentang Perlindungan Anak pada pasal 1 point (1), disebutkan bahwa :

Anak adalah seorang yang belum berusia 18 (delapan belas) tahun, termasuk anak dalam kandungan.

Kaitannya dengan ketentuan tersebut, oleh Poerwadarminta (1990 : 813), mengklasifikasikan batas usia seseorang sebagai berikut :

- Remaja adalah mulai dewasa, sudah sampai umur untuk kawin,

- Muda (tentang anak-anak laki-laki dan anak-anak perempuan);

- Mulai dewasa, yaitu mulai terbit rasa cinta birahi atau waktu anak-anak mulai terbit rasa cinta birahi.

Memperhatikan uraian di atas mengenai pengertian anak yang belum dewasa menurut peraturan perundang-undangan yang berlaku dan dikaitkan dengan beberapa pendapat dari ahli hukum, maka dapatlah dikatakan bahwa pengertian anak yang belum dewasa adalah seseorang yang di bawah 18 tahun serta termasuk anak yang masih dalam kandungan ibunya. pengertian barang masuk pula daya listrik dan gas. Meskipun barang tersebut tidak berwujud, akan tetapi dialirkan ke kawat atau pipa oleh karena itu mengambil beberapa helai rambut wanita tidak dengan izin wanita itu adalah termasuk pencurian, meskipun beberapa helai rambut tidak ada harganya.

\section{Unsur-unsur Delik}

Sebelum dikemukakan pengertian delik pencurian secara Yuridis, terlebih dahulu diuraikan pengertian istilah pencurian. Kata pencurian berasal dari kata dasar curi yang mendapat awalan "p" dan akhiran "an". Menurut Poerdarminta (1990:217), sebagai berikut :

Pencurian berasal dari kata dasar curi, yang berarti sembunyi-sembunyi atau diam-diam dan pencuri adalah orang yang melakukan kejahatan pencurian. Dengan demikian pengertian pencurian adalah orang yang mengambil milik orang lain secara sembunyi-sembunyi atau diam-diam dengan jalan yang tidak sah. Soerjono 
Soekanto (1987:10) menyatakan bahwa :

Secara umum pencurian adalah suatu tindakan seseorang dengan melawan hukum mengambil sesuatu barang yang sebahagian atau seluruhnya milik orang lain tanpa sepengetahuan yang berhak.

Dalam Kitab Undang-undang Hukum Pidana (KUHP), bahwa yang dimaksud dengan delik pencurian dapat dilihat dalam pasal 362, (Moeljatno, 1999 :128) yang rumusannya sebagai berikut :

Barang siapa mengambil barang sesuatu, yang seluruhnya atau sebagian kepunyaan orang lain dengan maksud untuk meiliki secara melawan hukum diancam karena pencurian, dengan pidana penjara paling lama lima tahun atau denda paling banyak sembilan ratus rupiah.

Berdasarkan rumusan pencurian dalam pasal 362 KUHP, maka dapat diketahui pengertian pencurian menurut perundang-undangan harus memenuhi unsur-unsur sebagai berikut :

1. Harus ada perbuatan mengambil;

2. Yang diambil harus sesuatu barang;

3. Barang itu atau seluruhnya atau sebagian kepunyaan orang lain;

4. Dengan maksud untuk memiliki barang dengan melawan hukum (melawan hak).

Pengertian hendak memiliki menurut Noyon Lengemeyer (Wirjono Prodjodikoro, 1980:17) adalah suatu perbuatan tertentu, suatu niat untuk memamfaatkan suatu barang menurut kehendak sendiri.

Sehubungan dengan itu, oleh Wirjono Prodjodikoro (1980 : 18 ) menyatakan bahwa:

Pengertian memiliki ialah berbuat sesuatu dengan sesuatu barang seolaholah pemilik barang itu dengan perbuatan-perbuatan tertentu itu si pelaku melanggar hukum.

Andi Zainal Abidin Farid (1987:274) menyatakan bahwa, hukum pidana, melawan hukum berarti bertentangan dengan undang-undang, hak orang lain serta bertentangan dengan hukum pidana tertulis (hukum pidana adat).

Dari beberapa pendapat di atas maka dapat ditarik kesimpulan bahwa, pelaku atau pembuat harus sadar dan mengetahui bahwa barang-barang yang diambilnya adalah milik orang lain, hendak memiliki adalh terwujud dalam kehendak dengan tujuan utama dari pelaku adalah memiliki barang tersebut secara melawan hukum (melawan hak).

\section{Terjadinya Kejahatan yang dilakukan Oleh Anak}

Sebagaimana kita telah ketahui bahwa Ada beberapa teori tentang sebab musabab terjadinya kejahatan yang dilakukan oleh anak, dapat dikelompokkan ke dalam 2 (dua) teori, yaitu: 


\section{a. Teori Sosiogenecis}

Dari berbagai pandangan yang telah kita ketahui, maka kita berpedoman pada teori ini menitik beratkan penelitiannya terhadap faktor-faktor yang bersifat sosiologis (murni) atau sosial psikologis, misalnya struktur sosial, tekanan kelompok dan lain-lain yang bersifat psikologis.

Sebagaimana pandangan Sutherland (kartini kartono, 1982:30), berpendapat bahwa:

Anak menjadi deliquent disebabkan oelh partisipasinya di tengah-tengah suatu lingkungan sosial, yang ide dan teknik deliquent tertentu dijadikan sarana yang efisien untuk mengatasi kesulitannya.

Demikian pula apa yang dikemukakan oleh Alam (1989:21), menyatakan bahwa:

Orang menjadi jahat karena keadaan lingkungan sosialnya yang mereka jahat. Kalau lingkungan sosialnya baik, maka orang itu menjadi baik pula. Orang atau anak itu menjadi jahat karena bergaul dalam waktu yang lama dengan penjahat, sehingga nilai-nilai yang dimiliki penjahat itu yang dituruti, dan nilai-nilai yang baik dalam masyarakat luas tidak diindahkannya.

Bawengan (1977:37) berpendapat bahwa, faktor lingkungan yang dimaksud disini termasuk kondisi sosial ekonomi, keluarga, serta sarana-sarana imegerasi yaitu fisik dan alam kewijaan misalnya, sex, pendidikan, alkoholisme dan keturunan.

b. Teori Subkultural

Untuk memahami Teori ini lebih banyak memperhatikan aktivitas aktivitas kelompok yang terorganisir dengansubkulturalnya.

Menurut Kartini Kartono (1982 : 31) bahwa ada 2 (dua) sebab kejahatan yang dilakukan oleh anak dari segi subkultural, yaitu :

1) Bertambahnya dengan cepat jumlahnya kejahatan, dan meningkatnya kualitas kekerasan serta kekejaman yang dilakukan oleh anak-anak yang memiliki subkultural delinquent.

2) Meningkatnya jumlah kriminalitas mengakibatkan sangat besarnya kerugian dan kerusakan secara universal, terutama terdapat di negara-negara industri yang sudah maju, disebabkan oleh meluasnya kejahatan yang dilakukan para pelaku anak-anak.

Sehingga tergambar dalam kaitannya dengan teori sebab-sebab terjadinya kejahatan yang dilakukan oleh anak, juga diperlukan sebagai usaha untuk menemukan penyebab terjadinya kejahatan anak, maka masih banyak lagi teori tersebut. Sebagai contoh teori yang dikemukakan oleh Soerjono Soekanto (Mulyana W. Kusumah, 1981 : 41) bahwa ada beberapa sebab musabab terjadinya kejahatan secara umum, sebagai berikut :

a. Adanya orientasi pada benda yang menimbulkan keinginan untuk mendapatkan 
materi dengan jalan mudah;

b. Tidak adanya penyaluran kehendak;

c. Adanya tekanan mental pada orang-seorang;

d. Kurangnya perasaan bersalah, dan adanya keteladanan yang kurang baik.

Berdasarkan dari teori-teori yang dikemukakan oleh beberapa ahli kriminologi tentang sebab musabab terjadinya kejahatan yang dilakukan oleh anak, maka upaya yang dilakukan dalam rangka pembentukan kepribadian anak secara utuh, menurut Simanjuntak (1984:102), antara lain :

a. Memberikan bimbingan kepada orang tua anak melalui pengaktifan pelaksanaan program PKK sebagai bentuk organisasi yang paling sederhana pada tingkat kelurahan, dengan memberikan penyuluhan kepada orang tua anak terhadap peningnya hubungan keakraban antara orang tua dengan anak, pembinaan keagamaan, mental dan budi pekerti yang baik kepada anak, cara-cara mengasuh dan mendidik anak;

b. Dijalin kerja sama antara guru dan orang tua dalam segala tingkat perkembangan masa sekolah anak-anak, baik dalam belajar di sekolah maupun di luar sekolah;

c. Meningkatkan aktivitas olah raga, seni dan reaksi kepada anak.

\section{PEMBAHASAN HASIL PENELITIAN}

\section{Terjadinya delik pencurian yang dilakukan oleh anak di Kota Palopo}

Masalah kejahatan adalah suatu masalah yang tidak pernah putus pada setiap pembahasan. Kejahatan itu bukan saja dilakukan oleh orang Dewasa tetapi juga sudah merambah ke usia anak. Namun demikian Sering kali kita hanya menyalahkan, mengapa anak melakukan suatu kejahatan ( delik ) tanpa mengetahui apa penyebab utamanya, inilah yang perlu dikaji secara mendalam Banyak hal atau faktor yang menyebabkan seseorang melakukan pencurian termasuk anak-anak yang melakukan seperti itu, hal seperti ini bukan hanya di kota besar terjadi tetapi juga sudah merambah ke daerah kabupaten. Untuk Kota Palopo hal seperti ini kasusnya cukup banyak Untuk mengetahui tingkat perkembangan delik pencurian:

\section{Tabel 1}

Delik Pencurian Yang Dilakukan Oleh Anak

Di Kota Palopo Dari Tahun 2013-2015

\begin{tabular}{|c|c|c|}
\hline Tahun & Frekuensi & Persentase \\
\hline 2013 & 11 & 26 \\
2014 & 8 & 20 \\
2015 & 15 & 54 \\
\hline Jumlah & 32 & 100 \\
\hline
\end{tabular}

Sumber Data : Kota Palopo, Tahun 2016

Dengan melihat dan memperhatikan mengenai alasan Polres Palopo 
menyerahkan anak tersebut kepada orang tua atau walinya, dan juga diselesaikan secara intern / kekeluargaan yang dikehendaki oleh pihak korban ( pemilik barang ) dengan orang tua/wali anak tersebut, hemat penulis bahwa penyelesaian yang dilakukan oleh aparat Polres Palopo telah sesuai dengan ketentuan perundangundangan yang berlaku, sebagaimana ditegaskan dalam Pasal 24 ayat (1) Undangundang Nomor 3 Tahun 1997 tentang pengadilan anak, bahwa :

Tindakan yang dapat dijatuhkan kepada Anak Nakal ialah :

a. Mengembalikan kepada orang tua, wali atau orang tua asuh;

b. Menyerahkan kepada Negara untuk mengikuti pendidikan, pembinaan, dan latihan kerja; atau

c. Menyerahkan kepada Departemen Sosial, atau Organisasi Sosial Kemasyarakatan yang bergerak dibidang pendidikan, pembinaan dan latihan kerja;

Alasan yang diselesaikan secara intern atau secara kekeluargaan, juga telah sesuai dengan ketentuan Pasal 367 KUHP yaitu pencurian dalam kalangan keluarga, karena pelaku pencurian tersebut adalah termasuk keluarga orang yang dicuri barangnya tadi. Jadi, baru dapat dituntut apabila ada pengaduan dari orang yang dicuri barangnya, dalam hal ini disebut delik aduan.

Adapun anak sebagai pelaku delik pencurian yang dikirim pada Kejaksaan Negeri Palopo, menurutnya bahwa Operasi pada Polres Palopo (wawancara tanggal 27 Mei 2016 ) karena anak tersebut sudah berapa kali melakukan kejahatan pencurian, dan sangat meresahkan warga masyarakat. Jadi, harus diberikan sanksi atau hukuman sesuai dengan perbuatannya melalui proses peradilan, dan nantinya mereka diberikan pembinaan- Sumber Data : Polres Palopo, Tahun 2016

Memperhatikan hal tersebut diatas di Kota Palopo nampak bahwa dengan demikian tabel tersebut memperlihatkan bahwa anak yang berumur 14 (tiga belas) tahun sampai 17 (sembilan belas) tahun sudah banyak yang melakukan suatu kejahatan yang seharusnya hal seperti itu belum bisa dilakukan karena semuanya dalam pengawasan orang tua dengan demikian dalam hal ini delik pencurian harus di berantas karena menyangkut masa depan anak. Dan apabila tidak diberantas maka, generasi muda kita akan semakin hancur ulah manusia yang tidak terkendali.

Demikian pula di Kota Palopo anak yang melakukan pencurian dengan melihat tingkat pendidikan yang begitu rendah sebagaimana halnya yang selalu kita lihat tingkat pendidikan anak yang melakukan delik pencurian yang terjadi di Kota Palopo. Hal ini penulis akan mengetengahkan dalam bentuk tabel sebagai berikut :

Jadi, dapat dikatakan bahwa semakin tinggi tingkat pendidikan, maka semakin cenderung menurun tingkat kejahatan khususnya yang dilakukan oleh anak di Kota Palopo. Sebaliknya, semakin rendah tingkat pendidikan, maka semakin cenderung pula meningkat terjadinya delik yang dilakukan anak. Mengingat selama ini perekembangan pencurian yang dilakukan oleh anak mempunyai kecenderungan meningkat. Padahal hal seperti ini harus diberantas karena pada umumnya yang 
melakukan pencurian adalah anak yang masih dibawah umur yang harus mendapat perlakuan yang baik.

\section{Usaha yang dilakukan untuk mengurangi Delik Pencurian bagi Anak di Kota Palopo}

Dengan banyaknya kejadian pencurian baik itu dilakukan oleh anak anak maupun yang dilakukan oleh orang dewasa, maka pemerintah dan penegak hukum serta tokoh masyarakat banyak melakukan usaha dan terobosan dalam rangka melakukan pengurangan terjadinya pencurian. hal-hal yang menyebabkan seseorang melakukan pencurian termasuk juga anak walaupun masih dibawah umur, namun demikian sebenarnya banyak faktor yang menyebabkan demikian diantaranya faktor sosial yang saling berhubungan atau mempengaruhi terjadinya delik pencurian yang dilakukan oelh anak, namun hanya membatasi diri pada hal-hal yang ada kolerasinya dengan delik pencurian yang dilakukan anak di Kota Palopo.

Dari hasil pengamatan dan wawancara yang dilakukan penulis dengan beberapa petugas Lembaga Pemasyarakatan Kota Palopo, maka dapat diketahui faktor-faktor yang mempengaruhi atau yang menyebabkan seorang anak melakukan delik pencurian di Kota Palopo, antara lain :

1. Faktor Lingkungan

2. Faktor Pergaulan;

3. Faktor sosial ekonomi;

4. Faktor tingkat pendidikan.

Berdasarkan hal tersebut diatas, maka penyebab terjadinya delik pencurian yang dilakukan oleh anak di Kota Palopo tersebut di atas, penulis akan menganalisis atau mengkaji lebih lanjut dari pendekatan segi kriminologi, sebagai berikut :

\section{a. Faktor Lingkungan Keluarga}

Yang meneyebabkan banyaknya pencurian yang dilakukan oleh anak adalah faktor yang menentukan baiknya seseorang termasuk anak itu sendiri adalah lingkungan dengan demikian lingkungan mempunyai peranan yang strategis dalam mempengaruhi watak seseorang. Dengan adanya lingkungan keluarga merupakan salah satu kelompok sosial yang pertama mempengaruhi kehidupan seorang anak. Keluarga merupakan permulaan hidup dari kehidupan seorang anak yang baru lahir. Dalam keluarga, seorang anak belajar memegang peranan sebagai makhluk sosial yang memiliki norma-norma dan kecakapan tertentu dalam pergaulan ditengah-tengah masyarakat. Pengalaman-pengalaman yang diperoleh dalam keluarga sangat menentukan cara-cara bertingkah laku seorang anak.

Sehingga dengn demikian halnya keluarga atau rumah tangga yang kurang harmonis dapat mempengaruhi psikologis buruk bagi perkembangan jiwa si anak, karena dasar pribadi si anak terutama dibentuk di dalam lingkungan rumah tangga. Misalnya kurangnya perhatian orang tua si anak, sehingga si anak tersebut merasa tidak disayangi, dan pada akhirnya ia frustasi, kecewa dan gelisah. Dengan 
demikian, sebagai akibat kekecewaan dan kegelisahan itu umumnya si anak secara spontanitas bertindak atau berprilaku yang negatif, seperti kebut-kebutan di jalan raya, suka mabuk-mabukan akibat minum-minuman keras, suka berkelahi, mencuri, dan kejahatan lainnya.

Dengan demikian, maka dapat dikatakan bahwa, salah satu faktor penyebab terjadinya delik pencurian yang dilakukan oleh anak adalah pengaruh lingkungan keluarganya sendiri.

\section{b. Faktor Lingkungan Pergaulan}

Betapa pentingnya pergaulan dalam keluarga, Selain faktor lingkungan keluarga yang mempengaruhi terjadinya delik pencurian yang dilakukan oleh anak di Kota Palopo, juga dipengaruhi oleh faktor lingkungan pergaulan.

Lingkungan yang buruk turut mempengaruhi yang lainnya. Satu contoh, dua orang anak yang masing-masing memiliki sifat yang jahat, yang satu berada pada lingkungan pergaulan yang memberikan kesempatan untuk berbuat jahat, sebaliknya anak yang satu berada di lingkungan yang baik itu untuk seterusnya bisa jadi sifat jahatnya tidak mempunyai kesempatan untuk berbuat jahat, karena tidak mengalami perkembangan atau tidak adanya kesempatan untuk berbuat jahat. Jadi, masalah lingkungan pergaulan di dalam hubungannya dengan kejahatan yang dilakukan oleh seorang anak, peranannya sejajar dengan masalah heriditas yang menurunkan sifat jahat seorang anak.

Kondisi ini, juga sering dikemukakan oleh kriminologi bahwa, lingkungan yang kurang bauk akan membuat orang menjadi kurang baik pula, dan lingkungan yang baik akan membuat orang menjadi baik pula.

Pernyataan kriminologi tersebut memang mempunyai nilai kebenaran, terutama apabila berhadapan atau dikaitkan dengan kejahatan seperti pencurian, pemerasan dan kejahatan lainnya yang terjadi di Kota Palopo. salah satu contoh yang sering terjadi di Kota Palopo adalah seorang anak bergaul dengan kelompok yang lingkungan pergaulannya yang suka membuat keonaran atau sering membuat keributan, seperti perkelahian (perkelahian kelompok), dan tidak menutup kemungkinan juga sering melakukan pencurian.

Menurut pengakuan salah seorang pelaku delik pencurian yang masih berada di Lembaga Pemasyarakatan Kota Palopo bahwa, ia melakukan pencurian karena terpengaruh atau dibujuk oleh teman pergaulannya. (wawancara tanggal 23 Mei 2016).

Jadi, masalah lingkungan pergaulan ini dalam hubungannya dengan delik pencurian yang dilakukan oleh anak yang terjadi di Kota Palopo, adalah hasil pencerminan atau tingkah laku dari apa yang selama itu diperoleh dari teman pergaulannya atau kelompok pergaulannya.

c. Faktor Kondisi Sosial Ekonomi

Yang paling dominan pengaruhnya terhadap manusia adalah kondisi sosial 
ekonomi sering dilakukan penelitian oleh para disiplin ilmu kriminologi untuk mempelajari hubungan kondisi sosial ekonomi dengan angka kejahatan dengan berpendapat bahwa, memang sepanjang masalah kondisi sosial ekonomi merupakan segi dari tingkah laku sosial, tentunya tidak dapat dikecualikan terhadap timbulnya berbagai macam tindakan kriminalitas di Kota Palopo.

Namun demikian, apakah hal tersebut juga dijelaskan dalam kaitannya dengan penyebab terjadinya delik pencurian yang dilakukan oleh anak. Hemat penulis, pencurian sebagai kejahatan dengan jenis apapun adalah sasaran utamanya adalah berupa harta benda. Dengan demikian, jelaslah bahwa faktor ekonomi juga turut terpengaruh. Hal ini identik yang dikemukakan oleh salah seorang anggota Polisi di Polres Kota Palopo bahwa, umumnya anak yang melakukan pencurian yang pernah ditahan atau diproses oleh aparat Polres Kota Palopo adalah kondisi ekonomi orang tuanya sangat lemah, orang tua anak tersebut rata-rata mempunyai pekerjaan tidak tetap dan bahkan diantaranya tidak mempunyai pekerjaan /pengangguran. Misalnya, orang tua anak tersebut hanya sebagai tukang becak, buruh bangunan.

Jadi disini faktor sosial ekonomi mempunyai hubungan erat dengan status pekerjaan. Pekerjaan seseorang yang tidak menentu (tidak tetap), rasanya memang agak susah untuk membiayai kebutuhannya sehari-hari, apalagi jika seseorang itu telah berkeluarga/berumah tangga dan telah mempunyai beberapa anak, maka kemungkinan anak-anaknya akan terlantar.

Kondisi sosial ekonomi orang tua anak yang melakukan pencurian, terbukti punya peranan yang cukup mendukung bagi seorang anak menjadi terlantar dan nakal atau jahat. Jadi, pada dasarnya kemiskinan akan mengakibatkan bahaya besar terhadap jiwa manusia, ditambah lagi kondisi negara kita ini sedang dilanda krisis ekonomi yang berkepanjangan dan semakin memburuk. Pemeratan pendapatan sosial ekonomi belum juga stabil dan seimbang, sehingga kesenjangan sosial sangat tinggi yang pada akhirnya akan mempengaruhi kestabilan mental anak, dan setiap orang pada umumnya.

Keadaan yang digambarkan di atas dapat dimengerti, karena proses-proses sosial ekonomi yang dialami oleh warga masyarakat tertentu meliputi pula dinamika sosial yang melatar belakangi perbuatan-perbuatan jahat, khususnya bagi lapisan masyarakat berstatus sosial ekonomi rendah, dan kini merupakan mayoritas penghuni lembaga-lembaga pemasyarakatan di Kota Palopo.

d. Faktor Rendahnya Tingkat Pendidikan

Namun demikian juga pendidikan tidak dapat diremehkan bahkan masalah pendidikan, maka lambat laun akan sampai pada suatu kesan bahwa misi utama pendidikan adalah untuk mewujudkan realisasi nilai-nilai budaya yang baik dan benar dari generasi ke generasi berikutnya. Dengan perkataan lain, bahwa pendidikan formal merupakan jalan utama pewarisan kebudayaan dari suatu generasi ke generasi lain yang terus menerus berlangsung secara berkesinambungan dari masa ke masa. 
Dalam proses pendidikan itu sendiri, sebenarnya berlangsung tidak hanya proses belajar saja, melainkan secara tidak langsung juga selalu desertai dengan proses imitasi atau pengambilan contoh suri teladan, dimana dapat mempercepat dan memperlancar berlangsungnya proses transfosmasi nilai-nilai kebudayaan dari generasi ke generasi anak didik.

Hal tersebut di atas, juga sering dikemukakan oleh ahli kriminologi bahwa, betapa pentingnya arti dari lembaga pendidikan dalam pembentukan watak manusia. Dari segi pembinaan bangsa, sekolah merupakan wadah untuk memupuk manusia-manusia yang kelak akan berguna bagi pembangunan dan kesejahteraan bangsanya dari segi kriminologi, sekolah pun berfungsi sebagai lembaga yang mampu untuk mencegah seseorang berbuat jahat.

Pendidikan formal merupakan ajang atau sarana pendidikan yang kedua setelah lingkungan keluarga terhadap seorang anak. Di kota besar di Indonesia dewasa ini, khususnya di Kota Palopo, masa anak atau remaja masih merupakan masa sekolah terutama pada masa-masa permulaan, dimana pada umumnya anak masih duduk dibangku Sekolah Dasar, Sekolah Menengah Tingkat Pertama atau setingkat. Namun hal tersebut pada kenyataannya tidak bisa dipungkiri bahwa, tidak sedikit dijumpai seorang anak yang putus sekolah disebabkan berbagai faktor yang menghambat proses pendidikan si anak yang bersangkutan, misalnya mereka menghambat atau anak tersebut tidak bisa lagi melanjutkan pada tingkat atau jenjang pendidikan selanjutnya, karena terbentur masalah biaya dalam hal ini orang tua anak tersebut tidak mampu membiayainya.

Tinggi rendahnya pendidikan formal seorang anak atau masyarakat pada umumnya, sangat menentukan dalam setiap bersikap dan bertindak dalam kehidupan sehari-hari ditengah-tengah masyarakat. Pendidikan formal adalah sangat penting bagi diri anak dalam pembentukan mental, kepribadian, pengetahuan dan keterampilan guna menyongsong hari esok yang lebih baik, demikian pula sebaliknya jika anak yang latar belakang pendidikannya sangat rendah atau bahkan tidak pernah sekolah, maka tentunya besar kemungkinan hari depannya akan kelabu sehingga potensi bersikap dan bertindak negatif.

Jadi, sekolah memegang peranan penting dalam kehidupan manusia, jika dibandingkan dengan lembaga-lembaga pendidikan lainnya. Dengan demikian pendidikan yang rendah maka dapat dikatakan sempit pula pemikirannya sehingga mudah terpengaruh pada tingkah laku yang kurang baik lewat perbuatan yang dapat merugikan orang lain.

Suatu hal yang perlu kita, tingkat pendidikan yang rendah tidak mutlak dikatakan faktor atau penyebab utama terjadinya delik pencurian, khususnya yang dilakukan oleh anak di Kota Palopo. Tetapi hal tersebut tidak dapat dipungkiri, karena yang berhasil terungkap atau yang diproses .

Sebagaimana diketahui bahwa kejahatan yang dilakukan oleh anak merupakan masalah aktual yang setiap saat menjadi pembicaraan dimana-mana, mengenai 
sebab-sebab terjadinya sangat beraneka ragam. Kejahatan yang dilakukan oleh anak tersebut, menyesuaikan diri dengan perkembangan yang sangat relatif, tergantung dari banyak hal. Oleh karena itu, cara penanggulangannya juga bervariasi dan disesuaikan pula dengan situasi dan kondisi dalam suatu lingkungan masyarakat. Jadi sifatnya relatif, dapat berlaku secara khusus maupun secara umum. Kebudayaan, pemerintah serta kebijaksanaannya turut pula mempengaruhi caracara penaggulangan kejahatan dalam hal ini delik pencurian yang dilakukan oleh anak.

Ada 3 (tiga) cara atau upaya yang dilakukan dalam rangka untuk menaggulangi delik pencurian yang dilakukan oleh anak di Kota Palopo, sebagaimana yang dikemukakan oleh pihak kepolisian Polres Palopo yakni bekerja sama dengan aparat pemerintah yang terkait seperti pejabat kejaksaan negeri, pengadilan Negeri, Lembaga Pemasyarakatan serta Departemen Sosial, adalah dilakukan dengan upaya, antara lain :

1. Pencegahan (preventif)

2. Pemberantasan (represif)

3. Perbaikan dan Pembinaan (rehabilitatif dan kuratif)

\section{Upaya Preventif}

Upaya Pencegahan ini, merupakan upaya yang dilakukan secara sistimatis, berencana, terpadu dan terarah kepada tujuan untuk menjaga agar kejahatan yang dilakukan oleh anak tidak timbul.

Adapun upaya preventif yang dimaksudkan disini, adalah:

a. Memberikan bimbingan kepada setiap orang tua anak, mengenai pentingnya hubungan keakraban dan cara hidup berkeluarga yang harmonis;

b. Pembinaan keagamaan, mental dan budi pekerti yang baik pada anak serta caracara mengasuh mendidik anak sampai dengan menanamkan disiplin kepada anak;

c. Dijalin kerjasama antara guru murid atau siswa yang erat, dalam segala tingkah perkembangan masa sekolah anak-anak terutama pada tingkat Sekolah Dasar, baik dalam proses belajar di sekolah maupun di luar sekolah;

d. Meningkatkan bimbingan dan penyuluhan keterampilan praktis yang berguna bagi kehidupan anak;

e. Meningkatkan aktivitas olahraga, seni dan rekareasi dan lain sebagainya.

2. Upaya Represif

Upaya represif atau pemberantasan ini adalah suatu upaya untuk mengatasi tindak kejahatan dalam hal ini delik pencurian yang dilakukan oleh anak yang sudah terjadi.

Pada prinsipnya setiap tindakan bentuk-bentuk kejahatan maupun kejahatan pencurian yang dilakukan oleh anak dalam proses sebagaimana pun harus bersifat mendidik dan menolong anak agar dapat menyadari akan perbuatannya, dan 
kembali kepada keluarga dan masyarakat dengan baik. Hal ini juga termasuk membantu petugas untuk mencari jalan atau cara-cara yang tepat terhadap masalahmasalah kenakalan atau kejahatan yang dilakukan oleh anak.

Dalam rangka menanggulangi delik pencurian yang dilakukan oleh anak di Kota Palopo secara represif, kesatuan Serse Polres Palopo melakukan tindakantindakan, antara lain :

a. Razia

Tindakan ini dilakukan terhadap :

- Tempat-tempat yang dianggap rawan terjadinya kejahatan yang dilakukan oleh anak seperti diadakan penertiban terhadap kelompok-kelompok anak yang sering mengganggu ketertiban umum.

- Mengadakan pendataan terhadap anak yang sering melakukan kejahatan

b. Pengusutan/Penyidikan

Dalam melakukan tindakan ini, pihak Polres Kota Palopo, terlebih dahulu memperhatikan dan mempertimbangkan penanganannya yang dianggap perlu, antara lain:

- Dalam melakukan interogasi dilakukan secara kekeluargaan dalam suasana yang tenang, sehingga anak tersebut merasa aman dan tidak takut;

- Dalam pemeriksaan bagi anak yang diduga melakukan kejahatan termasuk pencurian, diharuskan didampingi oleh orang tua/wali bila hal itu dianggap perlu;

c. Penahan

Prinsip-prinsip penahanan yang dilakukan oleh aparat Kota Palopo terhadap anak yang melakukan delik pencurian, diperlakukan sama dengan prinsipprinsip penahanan orang dewasa, terkecuali dalam hal-hal tertentu yang dianggap perlu demi menjaga stabilitas dan keamanan seorang anak.

Namun demikian ada upaya rehabilitas ini, adalah suatu upaya-upaya perbaikan dan pembinaan secara khusus, diartikan sebagai kelanjutan usaha memperbaiki kembali sikap dan tingkah laku anak yang melakukan kejahatan, dalam ini delik pencurian, dengan tujuan anak tersebut dapat memperoleh kembali kedudukan yang layak di tengah-tengah pergaulan masyarakat dengan bertingkah laku dengan baik.

\section{KESIMPULAN DAN SARAN}

Setelah mempelajari dan menganalisis berbagai hal yang berhubungan dengan delik pencurian yang dilakukan oleh anak di Kota Palopo dari tahun 2013 sampai dengan tahun 2015, maka penulis dapat menarik kesimpulan sesuai dengan rumusan masalah yang telah diidentifikasikan pada bagian terdahulu,sebagai berikut:

1 Faktor yang menyebabkan terjadinya delik pencurian yang dilakukan oleh anak 
di Kota Palopo dari tahun mengalami peningkatan yaitu faktor lingkungan keluarga, faktor lingkungan pergaulan, dan faktor lingkungan keluarga, faktor lingkungan pergaulan, dan faktor kondisi sosial ekonomi serta faktor minimnya tingkat pendidikan anak tersebut.

2 Adapun upaya yang dilakukan oleh aparat penegak hukum yang terkait utamanya aparat Kota Palopo untuk menaggulangi delik pencurian yang dilakukan oleh anak, yakni :

- Upaya preventif (pencegahan) memberikan bimbingan kepada orang tua anak mengenai pentingnya hubungan keakraban keluarga; pembinaan keagamaan, dijalin kerjasama antara guru murid tentang cara belajar di sekolah maupun di luar sekolah.

- Upaya Represif; yaitu melakukan tindakan razia, pengusutan / penyidikan, dan penahanan.

Adapun saran-saran sebagai berikut:

1. Mengingat faktor-faktor penyebab terjadinya delik pencurian yang dilakukan oleh anak di Kota Palopo, maka kepada aparatur pemerintah yang terkait harus bekerjasama dan penuh tanggung jawab untuk berusaha menciptakan mekanisme kerja yang cukup memadai, dan tidak hanya mengedepankan aspekaspek represif/penindakan bagi pelaku semata, tetapi sejauh mungkin pemerintah lebih memperhatikan dari segi upaya/usaha preventif seperti perbaikan sarana dan prasarana pendidikan, dan meningkatkan pemerataan kesempatan kerja sama serta lebih memperhatikan masyarakat golongan ekonomi lemah.

2. Sebaiknya aparat pemerintah selaku aparat penegak hukum bekerjasama pemerintah setempat mencari solusi yang tepat guna menaggulangi potensi kejahatan dalam hal ini delik pencurian.

\section{Daftar Pustaka}

Abdulsyani, 1987, Sosiologi Kriminalitas, Remadja Karya, Bandung.

Andi Zainal Abidin Farid, 1982, Azas-Azas Hukum Pidana, Pradnya Paramita, Jakarta 1987 Bunga Rampai Hukum Pidana, Pradnya Paramita, Jakarta.

A.S. Alam, 1989, Kejahatan Penjahat dan Sistem Pemidanaan, MIK, Ujung Pandang,

B. Simanjuntak, 1984, Latar Belakang Kenakalan Anak remaja, Bina Aksara, Jakarta.

G.W. Bawengan, 1977, Masalah Kejahatan Dengan Sebab Akibat, Prdanya Paramita Jakarta.

J.E. Sanetapy, 1982, Parados Dalam Kriminologi, Rajawali Press, Jakarta. 
Kartini Kartono, 1982, Patologi Sosial Kenakalan Remaja, C.V. Rajawali, Jakarta. 1983, Patalogi Sosial Kenakalan Remaja, C.V.Rajawali, Jakarta.

Moch. Anwar, 1994, Hukuman Pidana Bagian Khusus, Alumni, Bandung.

Moeljatno, 1983, Azas-Azas Hukum Pidana, Bina Aksara, Jakarta 1999, KUHP, Kitab Undang-undang Hukum Pidana, Bumi, Aksara, Jakarta.

Mulyana W.Kusuma, 1981, Aneka Permasalahan Dalam Ruang Lingkup kriminologi, Alumni, Bandung.

P.A.F. Lamintang, 1984, Dasar-Dasar Hukum Pidana Indonesia, Armico, Bandung.

Romli Atmasasmita, 1987, Problema Kenakalan Anak-Anak/Remaja, Armico, Bandung.

Rusli Effendy, 1986, Ruang Lingkup Kriminologi, Alumni, Bandung. 